\title{
The Study of Wind Potential in Merauke Used as an Energy Source
}

\author{
Daniel Parenden ${ }^{1}$, Peter Sahupala ${ }^{2}$ \\ Mechanical Engineering Department \\ Universitas Musamus \\ Merauke, Indonesia \\ 1'daniel@unmus.ac.id, 22pieter@unmus.ac.id
}

\begin{abstract}
Renewable energy is environmental-friendly energy compared to the conventional one. Wind energy is a renewable energy having big potential in supporting clean energy revolution in Indonesia. This research aims to calculate the wind energy potential power that can be used as a power plant. The data collection of the wind velocity is at Musamus University, Veterans' Housing, and Field of Pelayaran Lama Nowari Dormitory. The data collection is carried out in the morning, afternoon, and evening for 1 month, that is, from FebruaryMarch 2018. The wind velocity is measured using Anemometer. This research uses the equation of specific and big power of the wind kinetic power that can be converted into the useful power on the shaft. The measurement results of the wind velocity on the stated locations are: the average velocity at Musamus University is $3.51 \mathrm{~m} / \mathrm{s}$ with the average power potential of 32.129 Watt; the average velocity at Veteran's Housing is $3.11 \mathrm{~m} / \mathrm{s}$ with the average power potential of 24.783 Watt; the average velocity at the field of Pelayaran Lama Nowari Dormitory is $2.81 \mathrm{~m} / \mathrm{s}$ with power potential of 16.634 Watt. Based on the measurement result, the area or point with the wind potential as a power plant is at Musamus University campus, in which the average velocity is $3.51 \mathrm{~m} / \mathrm{s}$ and the average power is 32.129 Watt.
\end{abstract}

Keywords - Wind; Anemometer; Velocity,;Power

\section{INTRODUCTION}

The wind is all over the earth's surface. As long as the earth rotates, the wind will always exist. Its amount is very huge and will never run out. The source of this energy is more environmental-friendly because it will not result in the waste polluting environment. The wind is a renewable energy.

The wind exists if there is a different temperature. The wind moves from hot temperature to cold temperature. Hot wind from the equator moves to the poles. There are also sea wind, land wind, mountain wind, and valley wind. The wind even exists on the cloud height.

Climate change and global warming become a major concern in all around the world due to its effect on all aspect of human life. The use of conventional energy may cause emission of combustion that results in the greenhouse effect, dilutes the ozone layer, and causes climate change. Meanwhile, the use of fossil energy is increasing currently, but people have not focused on climate change [1]. In fact, a country's activity using conventional energy causes emission which obviously gives a global effect. Renewable energy is an environmental-friendly energy compared to the conventional one. Wind energy is a renewable energy having big potential in supporting clean energy revolution in Indonesia [2]. The wind is moving air, exist anywhere and anytime, that has been used as the ship driving when sailing a long time ago. However, with the development of technology, the wind can be used as the source of the power plant to meet the need for electricity. The advantages of the wind are [3] :

1. As a driving force for the windmill in agricultural activities.

2. As a power plant, the wind can rotate the turbine and convert it into electrical energy.

3. Support the biological process of the plant.

4. Support the drying process.

5. Support the sailing process (for a sailing boat)

The wind has given many advantages for life. It has an important role in the water cycle, bringing clouds resulted by the sea evaporation to all parts of the world so that the rain occurs throughout the world. The advantages of the wind have been felt all around the world. Based on the scientific theory, wind energy is an indirect form of solar energy. The wind is formed by the different temperature caused by the solar energy that is not unevenly spread on the surface of the earth (crust). When the sun is shining, the surface of the earth exposed to the sunlight is heating, so that the temperature of the surrounding air is increased. The hot air on the earth's surface rises, so the cooler air will fill the area left by the hot air. This air movement is what we call the wind.

The use of the wind as an energy resource in Indonesia is possible to develop in the future. Amidst the abundant wind potential in Indonesia's coastal area, the total capacity installed in the wind energy conversion system is currently less than 800 Megawatts [4].

Currently, the need for energy increases, either in developed or developing countries, such as Indonesia. It is known that more than $82 \%$ of commercial energy consumption is crude oil. As a result, Indonesia will experience an energy crisis one day.

According to that fact, it is important to look for other alternatives, instead of being dependent on the crude oil, using sources such as wood, coal, or other waste like straw, bagasse, 
sawdust, etc. Looking at the geography of Indonesia, which is located on the equator. Thus, it enables us to use the solar energy, the wind energy, or even energy from the wave power and different temperature at the sea.

Indonesia is located around the equator, which is the meeting area of Hadley and Walker circulation. This condition enables the wind potential to be used to develop a renewable energy. The alternative of the wind energy as the renewable energy needs further study in order to know the wind potential in each area in Indonesia.

The wind energy occurs based on the principle of the wind kinetic energy before and after passing the wind turbine. When passing through the wind turbine, the kinetic energy of the wind decreases (which is indicated by the reduced wind velocity). The lost kinetic energy is converted into mechanical energy that rotates the wind turbine, and this wind turbine is connected to the rotor of the generator.

Based on the classical physics, kinetic energy of an object with mass $\mathrm{m}$ and velocity $\mathrm{v}$ is $\mathrm{E}=0.5 \mathrm{~m} \cdot \mathrm{v}^{2}$, assuming that velocity $\mathrm{v}$ is not close to the speed of light. The formula is applied on calculating kinetic energy of the wind movement. Thus, it can be written as follow [5]:

$$
E=\frac{1}{2} m v^{2}
$$

Where:

$$
\begin{aligned}
& \mathrm{E}=\operatorname{energy}(\text { Joule }) \\
& \mathrm{m}=\text { air mass }(\mathrm{Kg}) \\
& \mathrm{v}=\text { wind velocity }(\mathrm{m} / \mathrm{s})
\end{aligned}
$$

If an air block has section $\mathrm{A}(\mathrm{m} 2)$ and moves in velocity $\mathrm{v}$ $\mathrm{m} / \mathrm{second}$, the amount of mass passing an area is:

$$
m=A v \rho
$$

Where:

$$
\begin{aligned}
& \mathrm{A}=\text { cross section }(\mathrm{m} 2) \\
& \mathrm{V}=\text { wind velocity }(\mathrm{m} / \mathrm{s}) \\
& \rho=\text { air velocity }(\mathrm{Kg} / \mathrm{m} 3)
\end{aligned}
$$

Thus, the power obtained from the wind energy can be calculated below:

$$
P=\frac{1}{2} \rho A v^{2}
$$

$$
\begin{aligned}
& \text { Where: } \\
& \qquad \begin{aligned}
\mathrm{P} & =\text { power per unit time }(\text { Watt }) \\
\rho & =\text { air velocity }(\mathrm{kg} / \mathrm{m} 3) \\
\mathrm{A} & =\text { section area }(\mathrm{m} 2) \\
\mathrm{v} & =\text { wind velocity }(\mathrm{m} / \mathrm{s})
\end{aligned}
\end{aligned}
$$

To find out the energy potential of each area, especially in Merauke Regency, it needs specific study. The method used is by calculating the potential of wind energy, wind direction, wind frequency with high potential to be used as an energy source, and there will be a more specific calculation.

\section{RESEARCH METHOD}

The research is conducted in 3 (three) different places in Merauke to get the wind velocity. The locations are:

a. Mopah Lama (Musamus University campus)

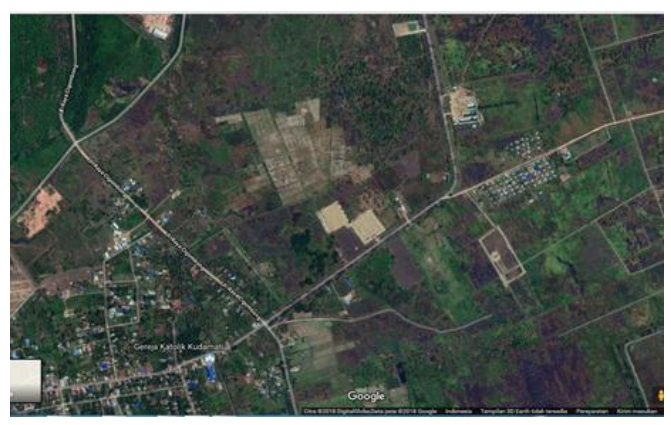

Fig. 1. satellite photos of the Musamus University area

\section{b. Veterans' Housing}

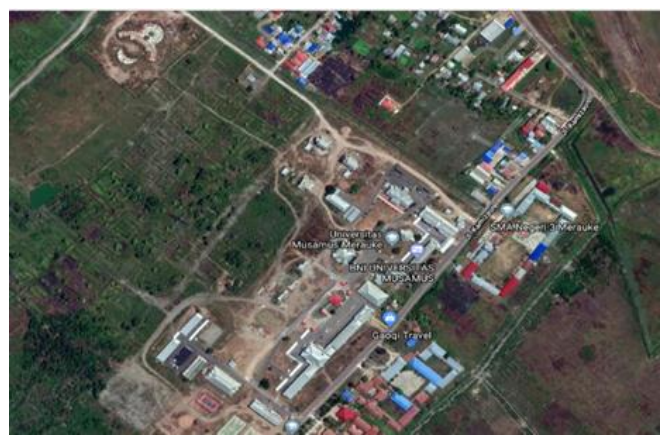

Fig. 2. satellite photo of veteran residential area

c. Field of Pelayaran Lama Noari Dormitory

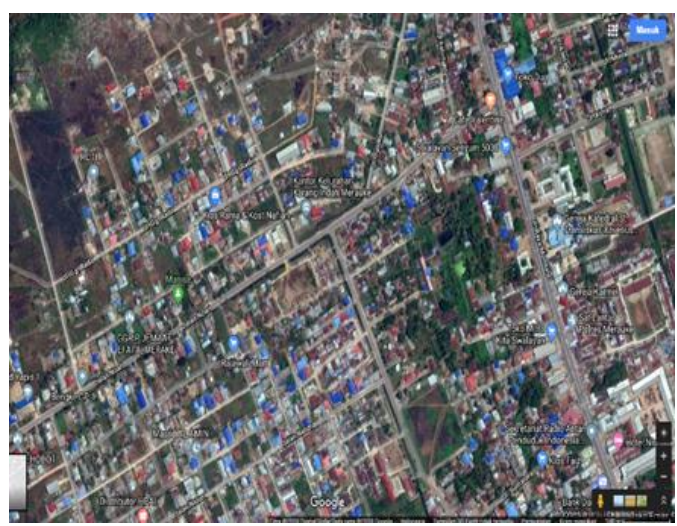

Fig. 3. satellite photo of Pelayaran Lama Noari Dormitory

The research is conducted in three different times, that is, morning at 8:00 am-10:00 am, afternoon at 11:00 am-1:00 pm, and evening at 3:00 pm- 5:00 pm (Indonesia Eastern Standard Time). The research is carried out for 1 month. The measurement result of the wind velocity in those three areas uses an anemometer, and then the 1-month-average wind velocity will be calculated as well. Thus, there will be obtained the wind energy potential used for the power plant. The research is done on February-March 2018. 
The collected data used consist of primary data, which is obtained from the measurement result of the wind velocity in three places using an anemometer, and secondary data gained from Meteorological, Climatological, and Geophysical Agency (BMKG) of Merauke Regency as the input data of this study. The data is used as the standard in calculating the wind for the power plant.

The data is then analyzed using the equation for specific power and wind kinetic energy that can be converted to be using power on the shaft.

\section{RESULT AND DISCUSSION}

The measurement result of the wind velocity in three locations is as follow:

\section{A. Mopah Lama (Musamus University campus)}

The measurement or the research is precisely conducted beside the Mechanical Engineering Laboratory. Based on the data collection for 7 days in Mopah Lama (Musamus University campus), the results are: the average wind velocity on the first day is $5.4 \mathrm{~m} / \mathrm{s}$, on the second day is $4.0 \mathrm{~m} / \mathrm{s}$, on the third day is $2.9 \mathrm{~m} / \mathrm{s}$, on the fourth day is $1.8 \mathrm{~m} / \mathrm{s}$, on the fifth day is $3.5 \mathrm{~m} / \mathrm{s}$, on the sixth day is $4.0 \mathrm{~m} / \mathrm{s}$, and on the seventh day is $3.0 \mathrm{~m} / \mathrm{s}$.

Based on the measurement data, it is seen that the highest wind velocity is on the first day, that is, $5.4 \mathrm{~m} / \mathrm{s}$ and the lowest one is on the fourth day, that is, $1.8 \mathrm{~m} / \mathrm{s}$, while the potential energy gained is 91.852 Joule.

After then, the calculation goes to find out power that can be used for the wind power plant through the following formula:

1. Air Mass:

Where:

$$
m=A v \rho
$$

$$
\begin{aligned}
& \mathrm{v}=5.4 \mathrm{~m} / \mathrm{s} \\
& \mathrm{A}=1 \mathrm{~m} 2 \\
& \rho=1.166636 \mathrm{Kg} / \mathrm{m} 3 \\
& \mathrm{~A}=\operatorname{section} \text { area }(\mathrm{m} 2) \\
& \mathrm{v}=\text { wind velocity }(\mathrm{m} / \mathrm{s}) \\
& \rho=\operatorname{air} \text { density }(\mathrm{Kg} / \mathrm{m} 3)
\end{aligned}
$$

Solution:

$$
\begin{aligned}
& \mathrm{m}=\mathrm{A} \times \mathrm{v} \times \rho \\
& \mathrm{m}=1 \times 5.4 \times 1.166636 \\
& \mathrm{~m}=6.3 \mathrm{~kg}
\end{aligned}
$$

2. The power raised :

Where:

$$
P=\frac{1}{2} \rho A v^{2}
$$

$\mathrm{P}=$ Power per unit time (Watt)

$\rho=$ Air density $(\mathrm{kg} / \mathrm{m} 3)$

$\mathrm{A}=$ Section area $(\mathrm{m} 2)$

$\mathrm{v}=$ Wind velocity $(\mathrm{m} / \mathrm{s})$

Solution:

$$
\begin{aligned}
& \mathrm{P}=0.5 \times \rho \times \mathrm{A} \times \mathrm{v}^{3} \\
& \mathrm{P}=0.5 \times 1.166636 \times 1 \times(5.4)^{3} \\
& \mathrm{P}=91.852 \text { (Watt) }
\end{aligned}
$$

\section{B. Veterans' Housing}

This research is conducted precisely at the side road of the people's house. Based on the data collection for 7 days in Veterans' Housing, the results are: the average wind velocity on the first day is $3.7 \mathrm{~m} / \mathrm{s}$, on the second day is $5.3 \mathrm{~m} / \mathrm{s}$, on the third day is $2.6 \mathrm{~m} / \mathrm{s}$, on the fourth day is $1.5 \mathrm{~m} / \mathrm{s}$, on the fifth day is $2.4 \mathrm{~m} / \mathrm{s}$, on the sixth day is $3.1 \mathrm{~m} / \mathrm{s}$, and on the seventh day is $3.2 \mathrm{~m} / \mathrm{s}$.

Based on the measurement result, the highest wind velocity is on the second day, that is, $5.3 \mathrm{~m} / \mathrm{s}$, and the lowest one is on the fourth day, that is, $1.5 \mathrm{~m} / \mathrm{s}$, while the potential energy obtained is 88.481 Joule.

After then, the power that can be obtained from the wind energy is calculated below:

1. Air Mass:

$$
\begin{aligned}
& \text { Where: } \quad m=A v \rho \\
& \text { v }=3.7 \mathrm{~m} / \mathrm{s} \\
& \mathrm{A}=1 \mathrm{~m} 2 \\
& \rho=1.166636 \mathrm{Kg} / \mathrm{s} \\
& \mathrm{A}=\text { Section Area }(\mathrm{m} 2) \\
& \mathrm{v}=\text { Wind velocity }(\mathrm{m} / \mathrm{s}) \\
& \rho=\text { Air density }(\mathrm{Kg} / \mathrm{m} 3) \\
& \text { Solution: } \\
& \mathrm{m}=\mathrm{A} \times \mathrm{v} \times \rho \\
& \mathrm{m}=1 \times 3.7 \times 1.166636 \\
& \mathrm{~m}=4.317 \mathrm{~kg}
\end{aligned}
$$

2. The power raised:

Where:

$$
P=\frac{1}{2} \rho A v^{2}
$$

$$
\begin{aligned}
& \mathrm{P}=\text { Power per unit time }(\text { Watt }) \\
& \rho=\text { Air density }(\mathrm{kg} / \mathrm{m} 3) \\
& \mathrm{A}=\text { Section area }(\mathrm{m} 2) \\
& \mathrm{v}=\text { Wind }(\mathrm{m} / \mathrm{s}) \\
& \text { Solution: } \\
& \mathrm{P}=0.5 \times \rho \times \mathrm{A} \times \mathrm{v}^{3} \\
& \mathrm{P}=0.5 \times 1.166636 \times 1 \times(3.7)^{3} \\
& \mathrm{P}=29.547 \text { Watt }
\end{aligned}
$$

\section{Field of Pelayaran Lama Noari Dormitory}

Based on the data collection for 7 days located in Nowari, the results are: the wind velocity on the first day is $4.2 \mathrm{~m} / \mathrm{s}$, on the second day is $3.5 \mathrm{~m} / \mathrm{s}$, on the third day is $2.2 \mathrm{~m} / \mathrm{s}$, on the fourth day is $1.3 \mathrm{~m} / \mathrm{s}$, on the fifth day is 2.9 $\mathrm{m} / \mathrm{s}$, on the sixth day is $3.1 \mathrm{~m} / \mathrm{s}$, and on the seventh day is $2.5 \mathrm{~m} / \mathrm{s}$.

Based on the measurement result, the highest wind velocity is on the first day, that is, $4.2 \mathrm{~m} / \mathrm{s}$, and the lowest 
one is on the fourth day, that is, $1.3 \mathrm{~m} / \mathrm{s}$, while the potential energy obtained is 43.217 Joule.

After then, the power that can be obtained from the wind energy is calculated below:

1. Air Mass:

Where:

$$
m=A v \rho
$$

$$
\begin{aligned}
& \mathrm{v}=4.2 \mathrm{~m} / \mathrm{s} \\
& \mathrm{A}=1 \mathrm{~m}^{2} \\
& \rho=1.166636 \mathrm{Kg} / \mathrm{s} \\
& \mathrm{A}=\operatorname{Section} \text { air }\left(\mathrm{m}^{2}\right) \\
& \mathrm{v}=\text { Wind velocity }(\mathrm{m} / \mathrm{s}) \\
& \rho=\text { Air Density }(\mathrm{Kg} / \mathrm{m} 3)
\end{aligned}
$$

Solution:

$$
\begin{aligned}
& \mathrm{m}=\mathrm{A} \times \mathrm{v} \times \rho \\
& \mathrm{m}=1 \times 4.2 \times 1.166636 \\
& \mathrm{~m}=4.900 \mathrm{~kg}
\end{aligned}
$$

2. The power raised:

Where:

$$
P=\frac{1}{2} \rho A v^{2}
$$

$$
\begin{aligned}
& \mathrm{P}=\text { Power per unit time }(\text { Watt }) \\
& \rho=\text { Air density }(\mathrm{kg} / \mathrm{m} 3) \\
& \mathrm{A}=\text { Section Area }\left(\mathrm{m}^{2}\right) \\
& \mathrm{v}=\text { Wind velocity }(\mathrm{m} / \mathrm{s}) \\
& \text { Solution: } \\
& \mathrm{P}=0.5 \times \rho \times \mathrm{A} \times \mathrm{v}^{3} \\
& \mathrm{P}=0.5 \times 1.166636 \times 1 \times(4.2)^{3} \\
& \mathrm{P}=43.217 \text { Watt }
\end{aligned}
$$

Based on the calculation of those three locations, fig 4 can be seen below:

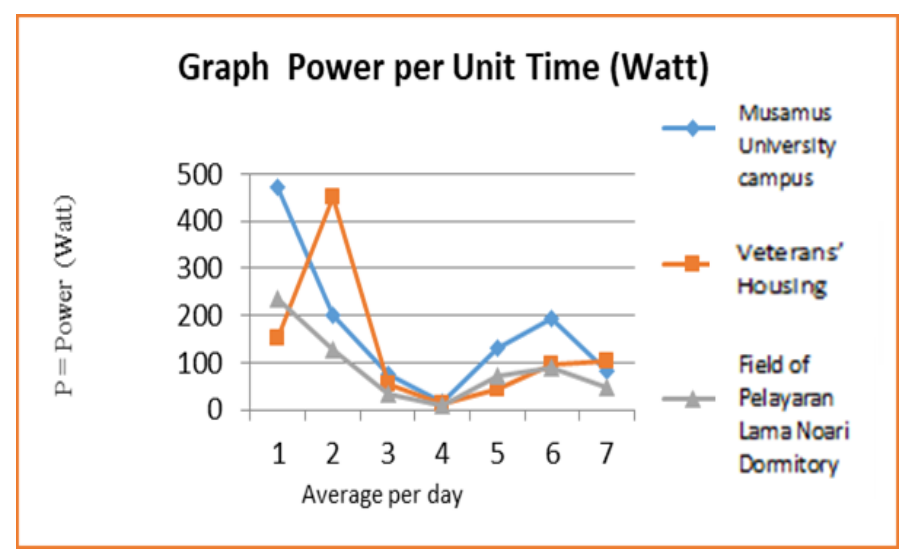

Fig. 4. The Average Power per Unit Time (Watt)

\section{CONCLUSION AND SUGGESTION}

\section{A. CONCLUSION}

Based on the research on the wind velocity measurement in three locations of data collection in Merauke, it can be concluded that the measurement conducted in Musamus University campus obtains the average velocity of $3.51 \mathrm{~m} / \mathrm{s}$ and the average power potential of 32.129 Watt; the measurement conducted in Veterans' Housing obtains the

average velocity of $3.11 \mathrm{~m} / \mathrm{s}$ and the average power potential of $24.783 \mathrm{Watt}$; the measurement conducted on the field of Pelayaran Lama Nowari dormitory obtains the average velocity of $2.81 \mathrm{~m} / \mathrm{s}$ and the average power potential of 16.634 Watt.

Based on the result, the area or point that has more potential on wind energy used as a power plant is at Musamus University campus with the average velocity of $3.51 \mathrm{~m} / \mathrm{s}$ and the average power obtained of 32.129 Watt.

\section{B. SUGGESTION}

Based on the research, it is suggested that the further research is conducted in other places in Merauke Regency so that the more valid data can be gained, and then it can be used as a recommendation to the government in planning the renewable energy potential of Merauke.

\section{ACKNOWLEDGEMENT}

This research was supported by Musamus University. We wish to thank rector of Musamus University for the support.

\section{REFERENCES}

[1] K. Hairiah, S. Rahayu, D. Suprayogo, and C. Prayogo, "Perubahan Iklim,’2016.[Online].Available: https://www.worldagroforestry.org/region/sea/publications.

[2] M.N. Habibie, A. Sasmito, and R. Kurniawan, Kajian Potensi Energi Angin Di Wilayah Sulawesi Dan Maluku, no. 2, 2011.

[3] A.D. Kusumawati, "Energi Baru Terbarukan Energi Angin(Bayu),’2017.[Online].Available: https://anggundwikusumawati.weebly.com/anggun-cerita-energi.

[4] A.Z. Zakaria, I. Abadi, and A. Musyafa, "Pemodelan Dan Pemetaan Potensi Energi Angin Menggunakan Jaringan Syaraf Tiruan (Jst) Di Bendungan Karangkates Kabupaten Malang," Pemodelan Dan Pemetaan Potensi Energi Angin Menggunakan Jar. Syaraf Tiruan Di Bendungan Karangkates Kabupaten Malang, pp. 1-8.

[5] S. Alimuddin and P. Daud, "Studi Potensi Energi Angin Di Kota Palu Untuk Membangkitkan Energi Listrik." 